$$
\begin{aligned}
& \text { حاوى سيستئين }
\end{aligned}
$$

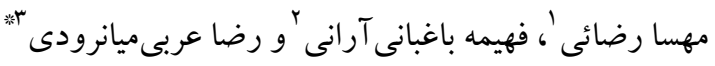

$$
\begin{aligned}
& \text { دريافت: } \\
& \text { 'خروه ميكروبيولوزى، دانشكدة علومزيستى، دانشگاه آزاداسلامى، واحد ورامين -يشوا، ورامين، ايران }
\end{aligned}
$$

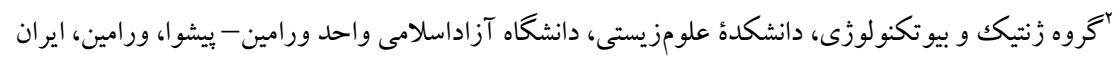

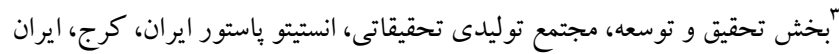

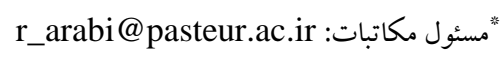

جإكيده. استريتو كيناز يكى از شناختهده ترين عوامل ترومبوليتيك با مصرف بالينى گسترده است. با وجود اين، كاربرد آن بهدليل ايمونوزن بودن، ايجاد عوارض

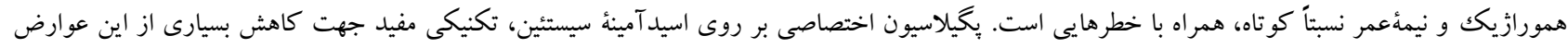

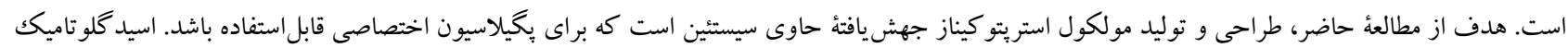

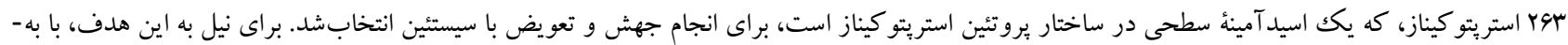

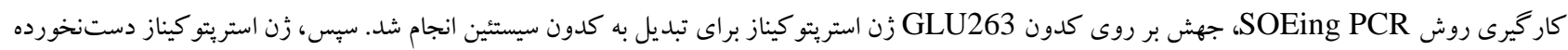

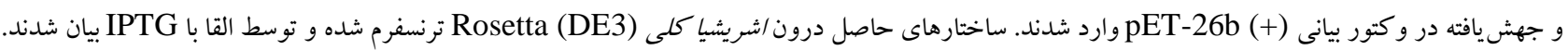

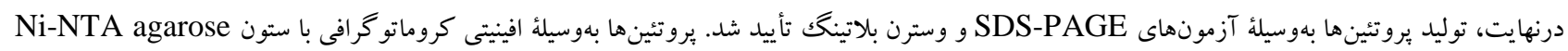

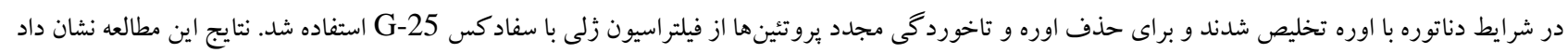

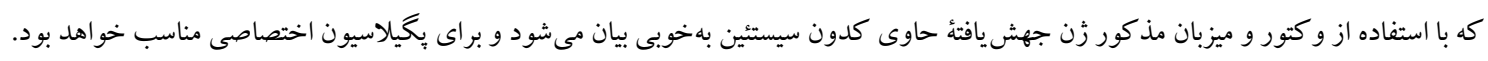

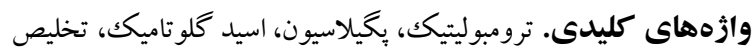

\title{
Point mutation in amino acid 263 of streptokinase gene as well as cloning and expression of the cysteine containing mutated protein \\ Mahsa Rezaei ${ }^{1}$, Fahimeh Baghbani Arani ${ }^{2} \&$ Reza Arabi Mianroodi ${ }^{3 *}$ Received 15.02.2016/ Accepted 04.09.2016/ Published 20.12.2016
}

${ }^{1}$ Department of Microbiology, Faculty of Biological Sciences, Varamin-Pishva Branch, Islamic Azad University, Varamin, Iran

${ }^{2}$ Department of Genetics and Biotechnology, Faculty of Biological Sciences, Varamin-Pishva Branch, Islamic Azad University, Varamin, Iran

${ }^{3}$ Research and Development Department, Research and Production Complex, Pasteur Institute of Iran, Karaj, Iran

*Correspondent author: r_arabi@pasteur.ac.ir

Abstract. Streptokinase is one of the best known thrombolytic agents with widespread clinical use. However, its use is not risk-free due to its immunogenicity, hemorrhagic complications and relatively short half-life in circulation. Specific PEGylation of cysteine residue is a useful technique for reducing most of these complications. The aim of this study was designing and producing a cysteine containing mutant of streptokinase, to be used for specific PEGylation. Glutamic acid 263, which is a surface amino acid in the structure of streptokinase protein, was selected for replacement with cysteine amino acid by site directed mutagenesis. The Glu263 codon was changed to cysteine codon by SOEing PCR technique. Then, the intact and mutated streptokinase genes were inserted into expression vector pET-26b $(+)$. The constructs were transformed to Escherichia.coli Rosetta (DE3) strain and the proteins were expressed by IPTG induction. The proteins were confirmed by SDS-PAGE and western blot analysis, purified by Ni-NTA agarose affinity chromatography under denaturing condition with urea and Sephadex G-25 column was applied to remove urea to refold the proteins. This study indicated that by using aforesaid vector and host, cysteine containing mutant gene is expressed well and it will be appropriate for specific PEGylation.

Keywords. thrombolytic, PEGylation, glutamic acid, purification

مقله

رگكها و منجربه بروز سكتههاى مغزى، قلبى، آمبولى ريوى و

حتى مرگك مىشود. در جنين وضعيتى تجويز درونر گى عوامل

$$
\text { لخته دونه نقص در دستخاه هموستاتيك مى توش اند موجب تشكيل }
$$


كرفتهاست كه ازآنجمله مىتوان به ايجاد جهش ( Wu et al.,

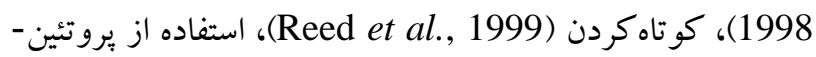
هاى فيوزن يا كايمريك (Shani et al., 2007)، كليكوزيلاسيون (Pratap et al., 2000) و : بحيلاسيون اشاره

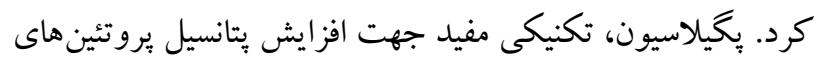
دارويى با هدف كاهش ايمنىزيى، افزايش نيمة عمر در بِلاسما و مقاومت آنها در برابر يروتئوليز است Chauhan \& Meena, 2011; Damodaran \& Fee, 2010; Kumar et al., 2010; Pizzo, 1991; Rajagopalan et al., 1985; Rachmawati .et al., 2014; Roberts et al., 2002; Veronese, 2001 بحيلاسيون در كذشته بهصورت غيراختصاصى و تصادفى روى

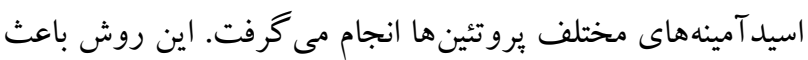

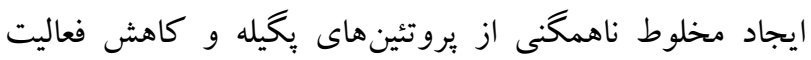

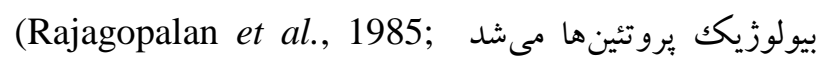

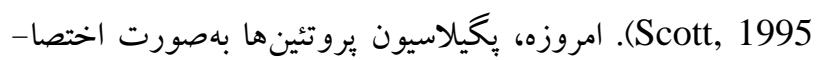

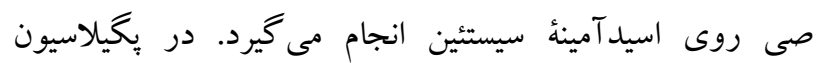

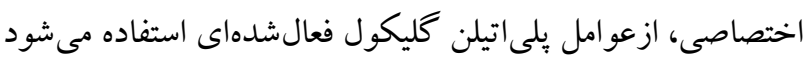
كه با گروه SH برهم كنش مى كنند و درواقع با اسيد آمينة سيستئين اتصال كووالانت برقرار مى كنند Kumar et al., 2012 Monzavi et al., 2010 توالى آمينواسيدى استريتوكيناز، اين يروتئين مولكول ايدهآلى

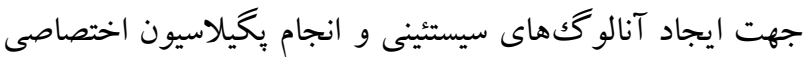
است. باستفاده از تكنيك DNA نوتر كيب، مىتوان سيستئين را

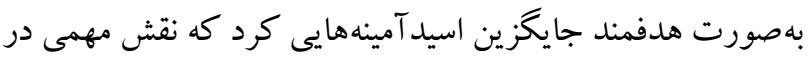
فعاليت يا تاخوردگى و ساختار استريتو كيناز ندارند؛ بهطورى كه جهش سيستئينى حاصل، كمترين تغيير را در فعاليت بيولوزيك ونك

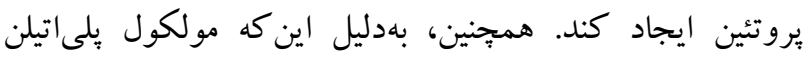

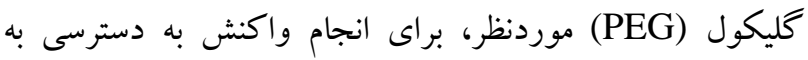

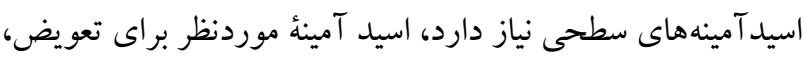

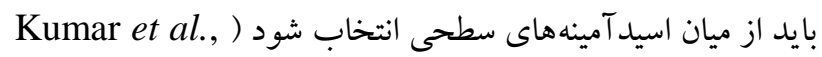
.(2012; Monzavi et al., 2010 Monzavi مطالعهاى صورت دادند كه در آن جهش جايكزين اسيدآمينٔ سيستئين به جاى اسيدآمينهُ سرين ^•r شد؛ نتايج اين مطالعه نشان

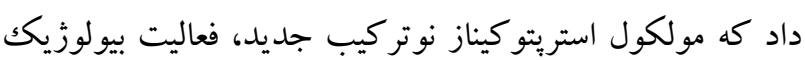

ترومبوليتيك مىتواند بيمار را از مركَ يا عوارض ناشىاز سكته نجاتدهد ) Baruah et al., 2005; Collen, 1990; Ghosh نt al., 2012

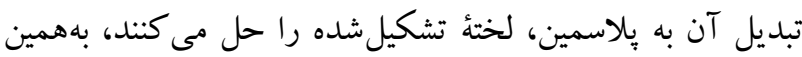

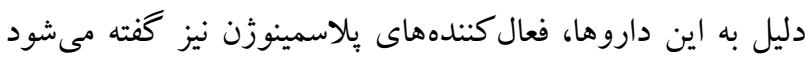
(Banerjee et al., 2004; Baruah et al., 2005; Del Zoppo, 2010

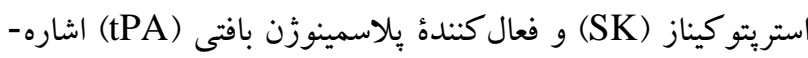
كرد. مطالعات وسيعى با هدف مقايسٔ كارايى كلينيكى استريتو كيناز و tPA انجام شدهاست، اما اين بررسىها بهطور كلى هلى برترى خاصى را در استفاده از اين دو دارو در مقايسه بايكديگر

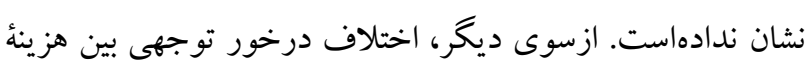
توليد و درمان با اين دو دارو وجود دارد، بهطورى كه هزينة تمام شدهُ درمان با استريتو كيناز درمقايسه با tPA بهطور درخور توجهى (Banerjee et al., 2004; Kumar et al., بايينتر است (2012

استريتو كيناز نوعى فعال كندة قوى پِلاسمينوزن، با مصرف بالينى

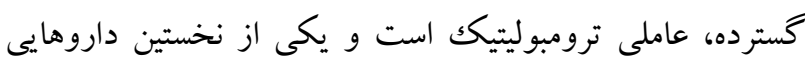
است كه توانست مجوز FDA را براى درمان سكتئ حاد قلبى كسب كند و در فهرست داروهاى ضرورى سازمان بهداشت (Banerjee et al., 2004; Baruah et al., جهانى است 2005; Sikri \& Bardia, 2007 FV زنجيرهاى متشكل از FIF اسيدآمينه با وزن مولكولى كيلودالتون است، كه بهوسيلة كونههاى مختلفى از استريتو كوكى -

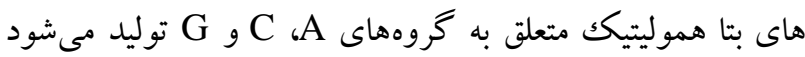
Banerjee et al., 2004; Baruah et al., 2005; Ghosh et ) al., 2012; Pimienta et al., 2007; Rother et al., 2013; Vellanki et al., 2013 استريتوكيناز، سببشده كه استريتو كيناز داروى ترومبوليتيك واليكي انتخابى بهويزه در كشورهاى درحال توسعه باشد. باوجود اين،

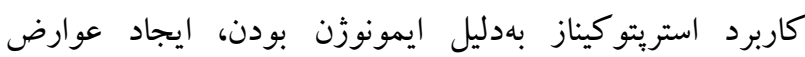

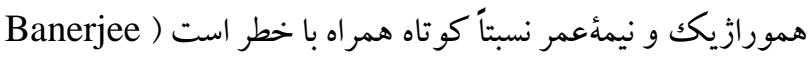
et al., 2004; Baruah et al., 2005; Sikri \& Bardia,

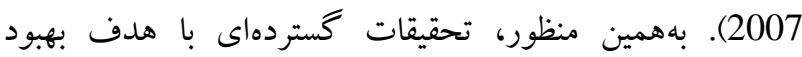
ويزگى هاى درمانى و كاهش عوارض جانبى استريتو كيناز انجام 
خواهد كرد، كلو تاميك اسيد سوY براى جايكزينشدن با اسيد آمينهُ سيستئين انتخاب شد.

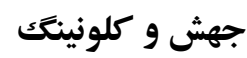

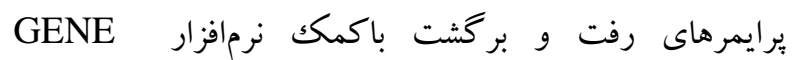
RUNNER (version 4.0.9 Beta) كرةجنوبى ساخته شدند (جدول (). با به كار گيرى روش وش

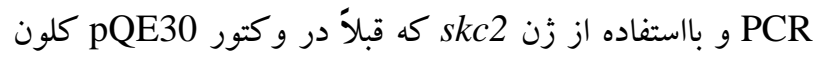

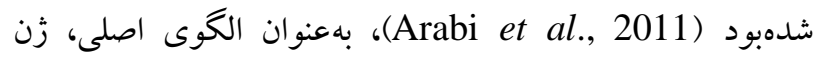

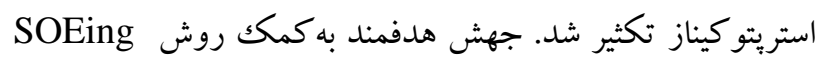
(Sambrook \& Russell, 2001) PCR استريتوكيناز حاوى جهش منجر شد. براى اين منظور، ابتدا دو واكنش PCR، جهت ساخت قطعات هميوشان حاوى جهش جايخزينى سيستئين، با اعمال يكك سيكل دماى واسرشت شدن فئن

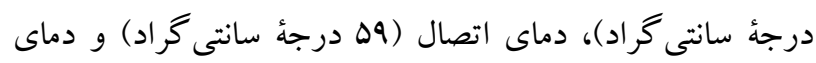

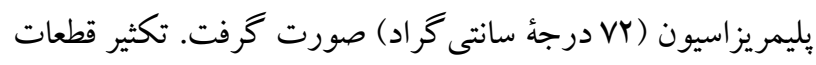

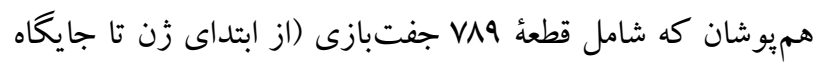

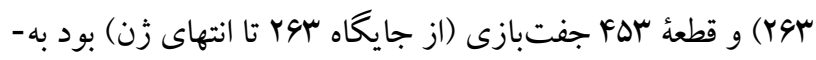

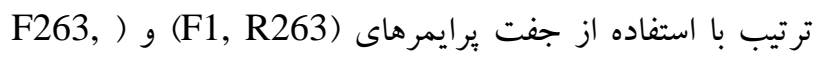

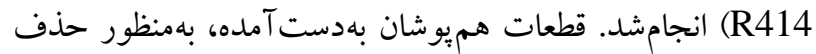

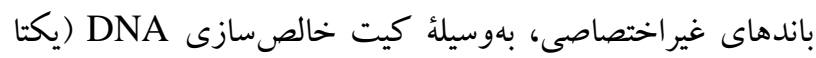

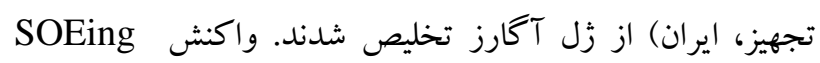

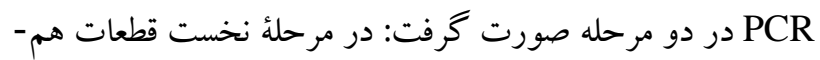

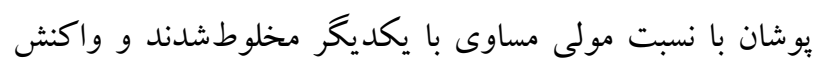

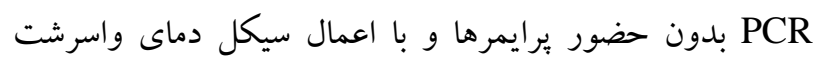

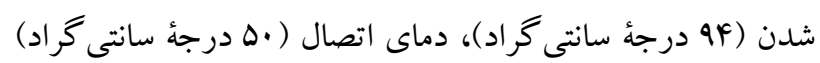
و دماى بليمريزاسيون (VY درجة سانتى گراد) انجام شد. بلافاصله

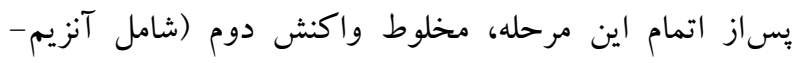
polymerase pfu DNA

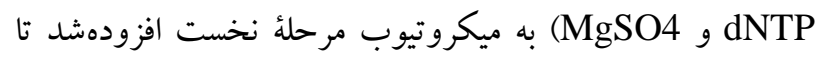
تكثير قطعه كامل استريتو كيناز حاوى جهش بلهوسيلة برايمرهاى

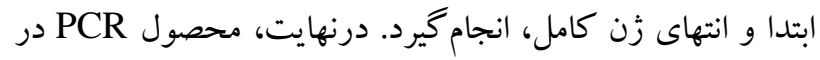

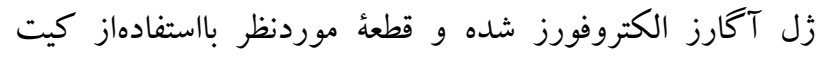
خالصسازى DNA (يكتا تجهيز، ايران) تخليصشد. زن دست-

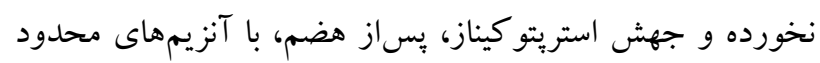

خود را حفظ كردهاست اما باوجود نتايج مناسب فعاليت بيولوزيك براى اين بروتئين جهش، هيج خزارشى تاكنون مبنى بر بحيلاسيون

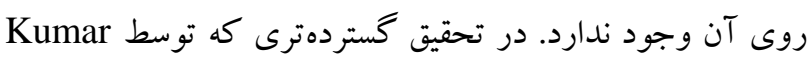

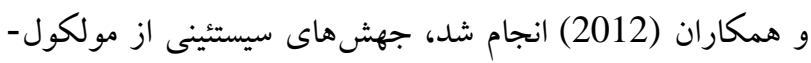

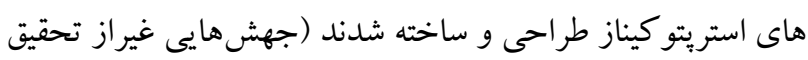

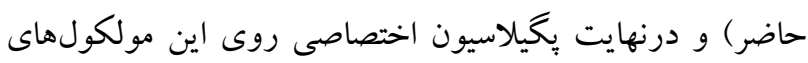

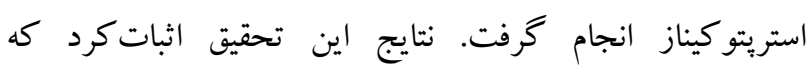
يخيلاسيون اختصاصى موجب بهبود خصوصيات استريتو كيناز از -

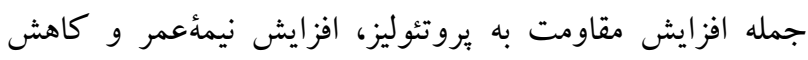

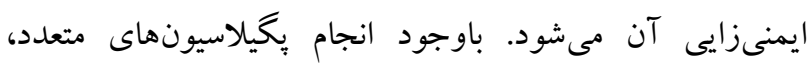

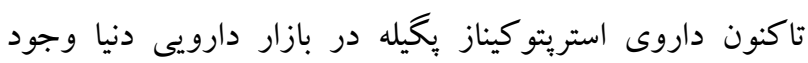
نداشتهاست. هدفاز مطالعهُ حاضر، طراحى و توليد مولكول استر -

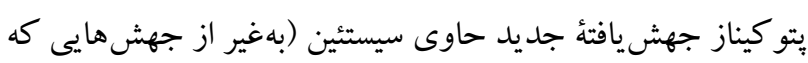

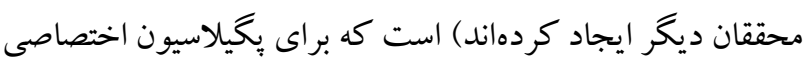
قابل استفاده باشد.

\section{مواد و روشها}

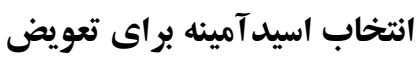
باستفاده از توالى اسيدآمينهاى يروتئين استريتو كيناز، كه در

Protein Databank (www.pdb.org) بايخاه اطلاعاتى SPDB viewer موجود است و با به كارگيرى نرمافزار

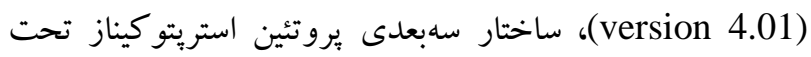
بررسى قرار گرفت و اسيد آمينهاى سطحى آن بهوسيلة نرمافزار

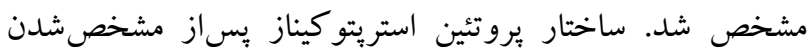

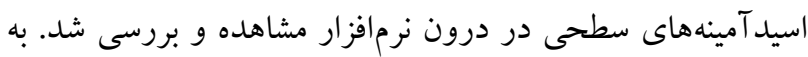

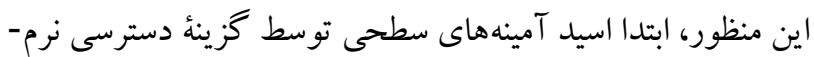
افزار مشخص شدند و بهصورت جداثانه در ساختار بروتئين

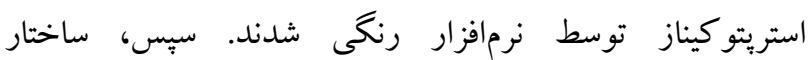

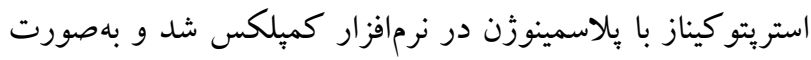

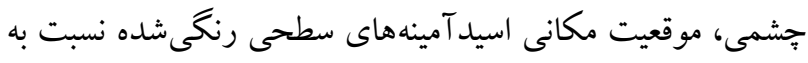

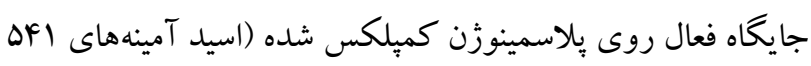

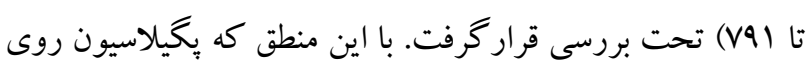

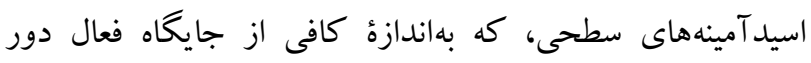

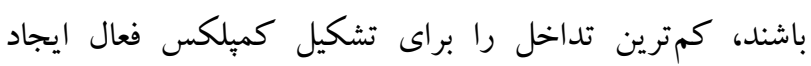


جدول ا - يرايمرهاى استفاده شده جهت تكثير استريتو كيناز جهش يافته و دستنخورده.

Table 1. Primers used for amplification of the intact and mutated streptokinase.

\begin{tabular}{|c|c|}
\hline 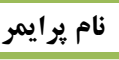 & 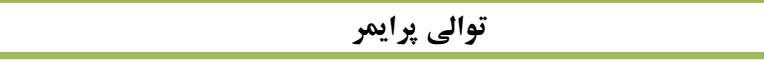 \\
\hline F1 & 5'-GACGAGACATATGATTGCTGGACCTGAGTG-3' \\
\hline R414 & 5'-GACACTCGAGTTTGTCGTTAGGGTTATCAG-3' \\
\hline F263 & 5'-CTGGTCTGAATGAATGCATAAACAACACTGAC-3' \\
\hline R263 & 5'-CAGGTCAGTGTTGTTTATGCATTCATTCAG-3' \\
\hline
\end{tabular}

جايگاه شناسايى آنزيم هاى محدود كننده بهصورت خط زير و كدون سيستئين بهصورت بررنك نشان دادهشداست.

Underlined letters represented restriction enzymes recognition sites and bold faced letters represented mutated codon

آنزيم HRP بهعنوان آنتىبادى ثانويه، بساز افزودن محلول DAB، وجود باندهاى اختصاصى استريتو كيناز دستنخورده و جهش يافته تحت بررسى قرار گرفت.

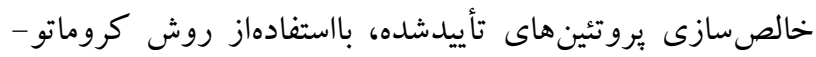
كرافى تمايلى با ستون Ni-NTA agarose

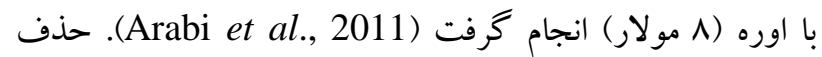

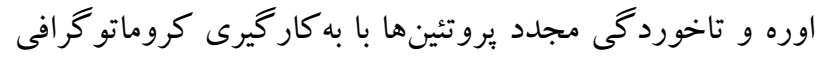

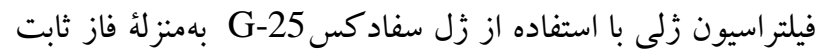
و بافر حاوى

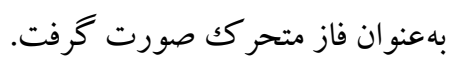

\section{نتايج}

باستفادهاز نرمافزار SPDB viewer، ساختار سهبعدى : يروتئين

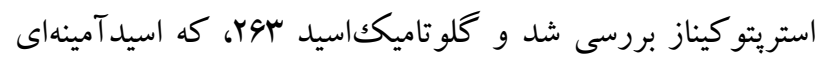
سطحى است، جهت انجام جهش جايخز ينى با اسيدآمينه سيستئين انتخاب شد. همانطور كه در شكل r مشاهده مى جـوده، اسيد آمينة كلو تاميكاسيد بوץ در دمين بتا قراردارد و داراى فاصلة كافى بان

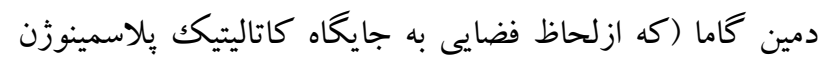
نزديك است) است. بهمنظور ايجاد جهش، ابتدا قطعات هميوشان إنهان

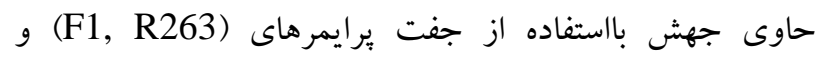
(F263, R414) قطعات در مرحله بعدى با كمكك روش SOEing PCR هم يوشان شدند و قطعه كامل حاوى جهش ايجاد شد (شكل مB م). درنهايت

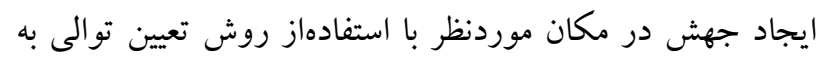
تأييد رسيد (شكل \&). زن دستنخورده و جهش يافتئه استريتو كيناز،
كنندة Fermentas, Romania) NdeI/XhoI pET-26b(+) دستنخورده و جهشيافته كه بهترتيب pETSK263Cys و

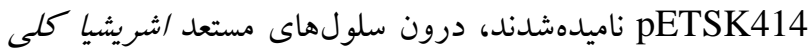

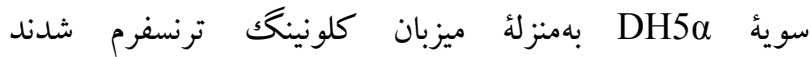

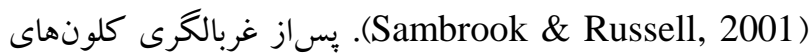
حاوى وكتور موردنظر در محيط كشت كانامايسيندار، تخليص

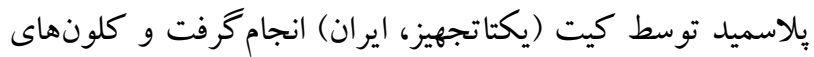
حاوى زن موردنظر بهوسيلة هضم با آنزيمهاى محدودكننده

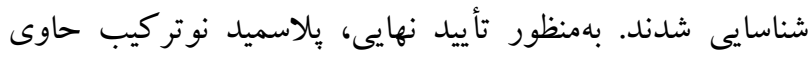
استريتو كيناز جهشيافته، براى اطمينان از وجود كدون اسيدآمينٔ

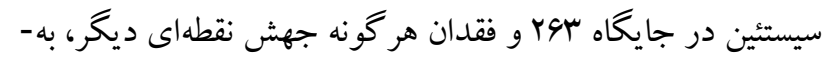

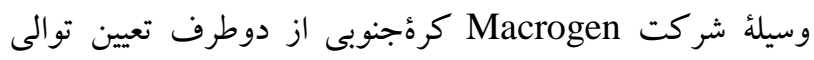

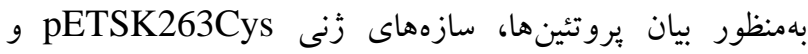

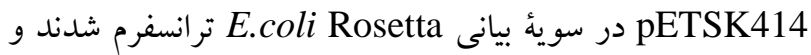
يساز كشت در محيط TY2X القاء بيان بروتئين ها بهوسيلة با غلظت نهايى يك ميلىمولار صورت گرفت و (Sigma, USA) بيان يروتئينها بااستفادهاز تحليل SDS-PAGE ارزيابى شد.

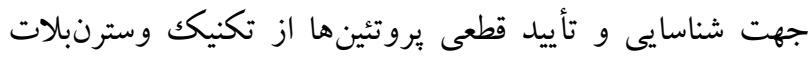

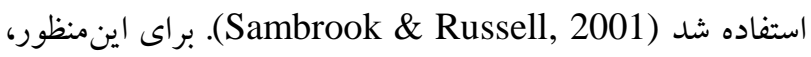
ابتدا باندهاى مربوط به يروتئين استريتوكيناز دستنخورده و

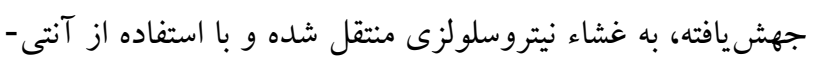

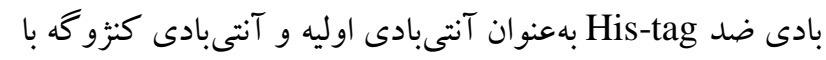




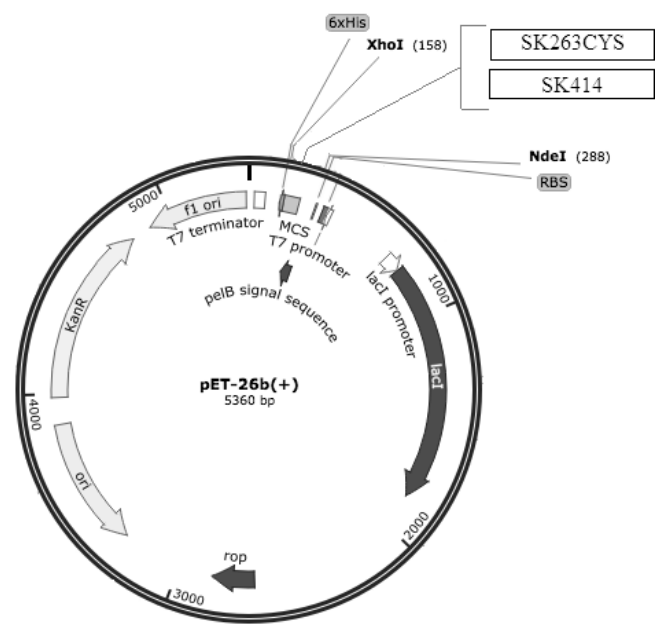

شكل ا- نمايى شماتيك از وكتور pET-26b و جايكاه ورود رُن استريتو كيناز. زُنهاى دستنخو رده و جهشيافته استريتو كيناز از طريق جايكاههاى برش آنزيمهاى XhoI و NdeI

Fig. 1. Schematic illustration of pET-26b vector and insertion site of streptokinase gene. Intact and mutated streptokinase genes were inserted into the vector by $\mathrm{NdeI}$ and $\mathrm{XhoI}$ restriction sites.

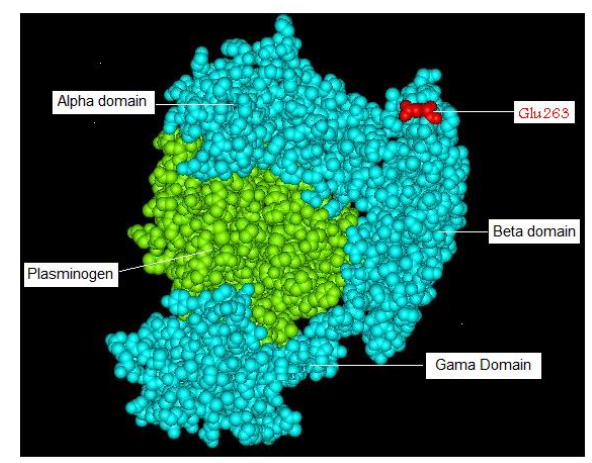

شكل r- ساختار كمِلكس استر يتو كيناز - بِلاسمينوزُن.

Fig. 2. Structure of streptokinase-plasminogen complex.

مشاهدهنشد (نتايج نشان داده نشدهاند). ازاين رو، سازهها درون

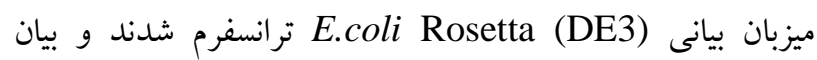

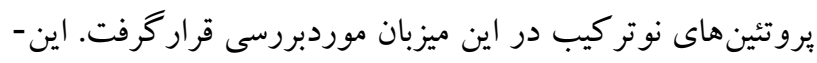

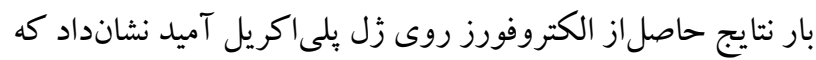
هم بروتئين دستنخورده و هم بروتئين جهشيافته بهطور كاملاً

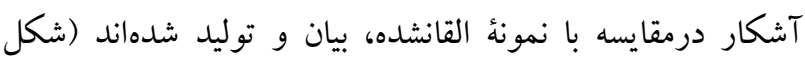
هA اختصاصى مربوط به بروتئينهاى استريتو كيناز جهش و دست-

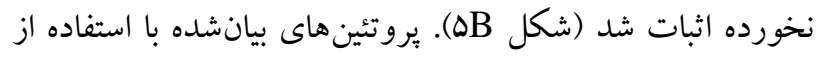

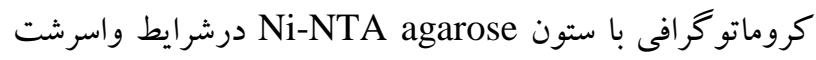
با درجهُ خلوص بيشاز .9 درصد خالص شدند. بهمنظور تاخورد گحى مجدد بروتئين ها و حذف اورهُ مورداستفاده در مر احل
در جايكاه NdeI/XhoI و كتور (+) pET-26b كلونشد و سازههاى زنى حاصل بهنامهاى pETSK263Cys و pETSK414 درون باكترى E.coli DH5a ترنسفرم شدند. باستفادهاز هضم آنزيمى، كلونينك زن دستنخورده و جهشيافته استريتو كيناز در و كتور (+pET-26b موردتأيد قرار گرفت و تعيين توالى مجدد زن در سازه pETSK263Cys، ايجاد جهش در نقطة موردنظر (جايگاه بوץ) و فقدان هر گونه جهش نقطهاى ديخر را تأييدكرد. بهمنظور بيان بروتئين هاى دستنخورده و جهش يافته، سازههاى به -

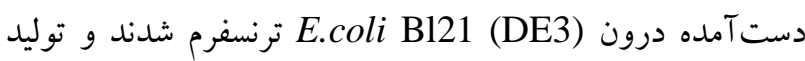
يروتئينها باستفاده از IPTG القاء شد. بساز بررسى سلولهاى القا شده بهروش SDS-PAGE، هيج باند يروتئينى كيلودالتونى روى زل بلى اكريل آميد (درمقايسه با نمونهُ القاءنشده) 


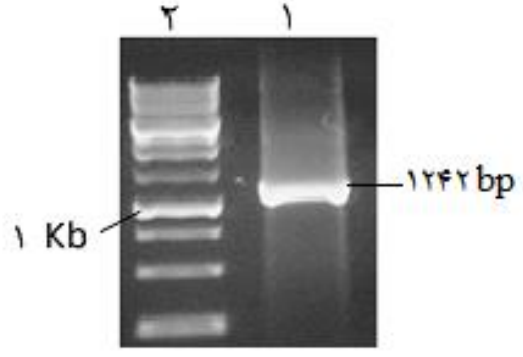

A

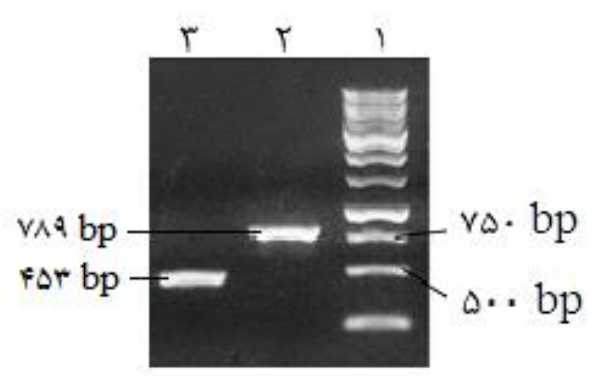

B

شكل r- الكتروفورز محصولات PCR روى زل آكارز. A: تكثير قطعات هميوشان حاوى جهش؛ ستون ا، ماركر (1kb(SM0313 شركت فرمنتاس؛ ستون rا،

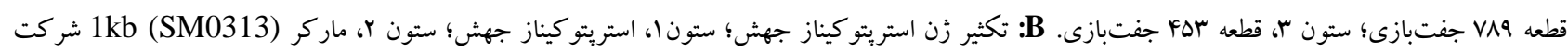

Fig. 3. Gel electrophoresis of PCR products. A: Amplification of overlapped fragments containing mutation; lane 1, Fermentas DNA ladder,1kb (SM0313); lane 2, 789 base pair fragment; lane 3, 453 base pair fragment. B: Amplification of mutated streptokinase gene; lane 1, mutated SK; lane 2, Fermentas DNA ladder, 1kb (SM0313).

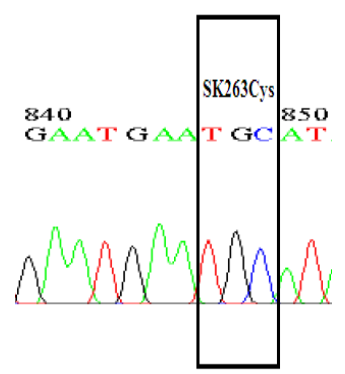

شكل ع- توالى نو كلئو تيدى آنالو گك سيستيني SK263Cys كه كدون سيستئين در آن مشخص شده است.

Fig. 4. Nucleotide sequence of cysteine analogue SK263Cys that cysteine codon is distinct in it.

مولكول استريتو كيناز جهشيافته حاوى سيستئين دستيافت - (Kumar et al., 2012; Monzavi et al., 2010) اساس، در مطالعه حاضر تلاش شده است تا با طراحى و ساخت استريتو كيناز جهش جديد حاوى سيستئين (به غير از جهشهايى كه محققان ديخر ايجاد كردهاند)، امكان انجام بِيَلاسيون اختصاصى روى اين بروتئين دارويى در ايران فراهم شود. جهت Kumar et al., ) تعيين جايگاه جهش، همانند مطالعات مشابه (2012; Monzavi et al., 2010 بودن و سطحىبودن اسيدآمينهُ انتخابى و دوربودن آن از جايكاه فعال يروتئين يلاسمينوزن درنظر گرفته شو و باتوجه به نتايج

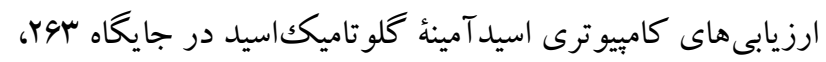
بهمنظور جايخزينى با اسيدآمينهُ سيستئن انتخاب شد. بررسى اسيدى ساختارى استريتو كيناز بهصورت جشمى در نرمافزار SPDB نشانداد كه اسيدآمينٔ انتخابشده هم سطحى بوده و
تخليص، كه مىتوانست موجب واسرشت شدن و غيرفعالشدن يروتئينها شود، كروماتوكرافى فيلتراسيون زلى انجام گرفت. نمودارهاى حاصلاز فيلتراسيون زلى بروتئين استريتوكيناز دست نخورده و جهش باستفادهاز ستون سفادكس G-25، نشاندهنده خروج اوره از محلولهاى يروتئينى بود (شكل 9). محلولهاى يروتئينى بِاز تعويض بافر، فاقد هر گونه رسوب و تجمع بروتئينى بود. اما نتايج غلظتسنجى نشانداد كه محلولهاى يروتئينى تقريباً دوونيم بر ابر رقيق شدهاند.

يكى از مهم ترين روشهاى بهينهسازى استريتو كيناز، يِخيلاسيون اختصاصى روى اسيدآمينه سيستئين است. نتايج مطالعات بيشين نشان مىدهد كه درصورت توجه به ويزً گیى هاى ساختارى و عمل كردى بروتئين استريتو كيناز، مىتوان باحفظ فعاليت بيولوزيك به به به به 


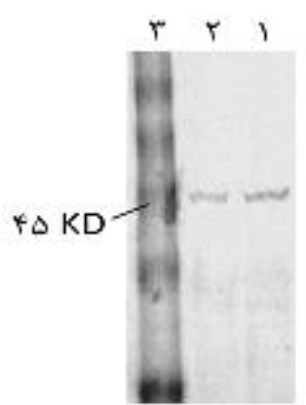

A

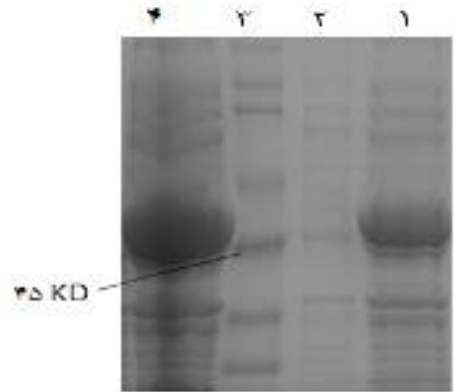

B

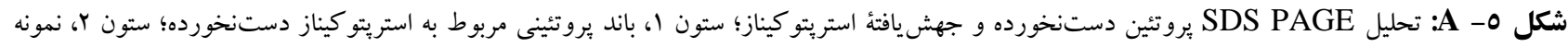

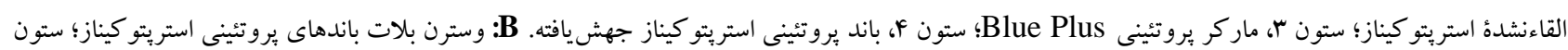

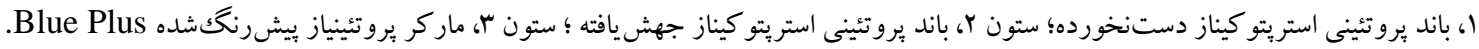

Fig. 5. A: SDS-PAGE analysis of intact and mutated streptokinase proteins; lane 1, intact streptokinase; lane 2, noninduced SK; lane 3, Blue Plus protein marker; lane 4, Mutated streptokinase. B: Western blot analysis of SK proteins; lane 1, intact streptokinase; lane 2, Mutated streptokinase; lane 3, pre-stained Blue Plus protein marker.

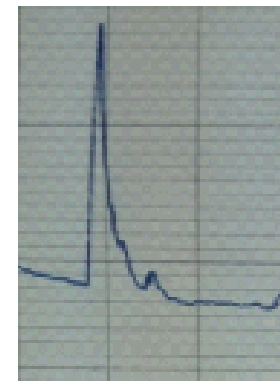

A

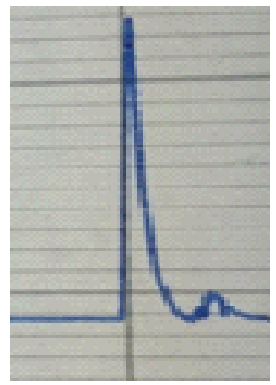

B

شكل 7 - نمودار كروماتو گرافى فيلتراسيون زلى؛ نمودار A: جداسازى اوره از استريتو كيناز جهشيافته، B: جداسازى اوره از استريتو كيناز دستنخورده؛ در هر دو

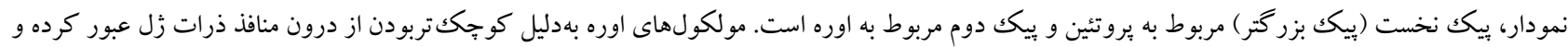

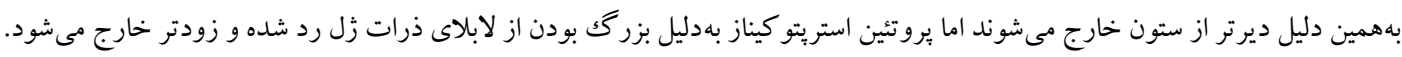

Fig. 6. Diagrams of gel filtration chromatography; diagram A: separation of urea from mutated SK; diagram B: separation of urea from intact SK; in both of diagrams the first peak is related to protein and the second peak is related to urea.

كه سوية (DE3) موجب افزايش بيان يروتئين ها مىشود. علت اين مسئله، مىتواند متفاوتبودن كد اسيد آمينهاى مورداستفاده در اين دو سويه باشد؛ بهاين معنى كه احتمالاً سوية Rosetta بهدليل دارابودن كمياب، موجب بيان كدونهايى مىشود كه بهندرت در E.coli استفاده مى شود؛ در نتيجه استفاده از اين سويه موجب افزايش بيان بروتئين ها مىشود

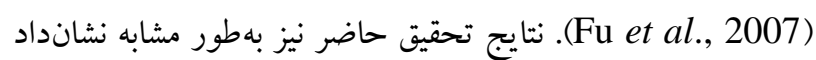
كه باستفادهاز سويه (DE3) ميزان قابل توجهى افزايش مىيابد. يكىاز مهم ترين مراحل توليد
بهاحتمال زياد يساز يُخيلاسيون تداخلى در ايجاد كميلكس با يلاسمينوزن ايجاد نخواهدكرد. كفتنى است كه در هيجيك از

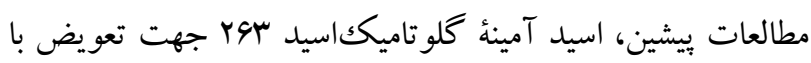
اسيدآمينهُ سيستئين استفاده نشدهاست. نتايج حاصلاز الكتروفورز يروتئينها روى زل بلى اكريل آميد نشانداد كه بروتئينها در سوية

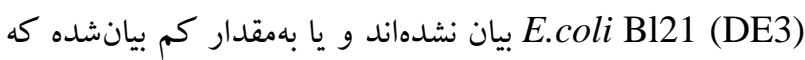
با روش الكتروفورز قابل رديابى نبودند. در مطالعهُ ديخرى كه باهدف مقايسهُ ميزان بيان بروتئين ها در سويههاى E.coli Rosetta و (DE3) انجام گرفته بود، نشان دادهشد (DEccoli B121 (DE3) 


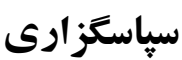

هزينههاى مالى اين تحقيق، كه قسمتى از طرح 1. V است، از

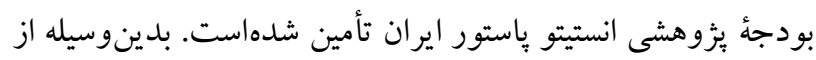
حمايتهاى دكتر آقاصادقى رييس بخش هياتيت و ايدز انستيتو يإستور ايران و كمك هاى تكنيكى خانم متولى قدردانى مى شود.

\section{REFERENCES}

Arabi, R., Roohvand, F., Noruzian, D., Aghasadeghi, MR., Memarnejadian, A., Khanahmad, H., Sadat, M. and Motevali, F. 2011. Cloning and expression of truncated and intact streptokinase molecules in E.coli and evaluation of their biological activities. - J. Agricul. Biotech. 2: 55-67.

Banerjee, A., Chisti, Y. and Banerjee, U.C. 2004. Streptokinase - a clinically useful thrombolytic agent. - Biotec. Adv. 22: 287-307.

Baruah, D.B., Dash, R.N., Chaudhari, M.R. and Kadam, S.S. 2005. Plasminogen activators: A comparison. - Vascul. Pharmacol. 44: 1-9.

Bornhorst, J. and Falke, J.J. 2000. Purification of proteins using polyhistidine affinity tags. - Methods Enzymol. 326: 245-254.

Chauhan, S. and Meena, S. 2011. Pegylation - A Sunrising Technology. - IPS 1: 18-24. Collen, D. 1990. Coronary thrombolysis: streptokinase or recombinant tissue-type plasminogen activator. - Ann. Intern. Med. 112: 529538.

Damodaran, V.B. and Fee, C.J. 2010. Protein PEGylation: An overview of chemistry and process considerations. Eur. Pharmace. Rev. 15: 18-26.

Del Zoppo, G.J. 2010. Plasminogen activators in ischemic stroke: introduction. - Stroke 41: 39-41.

Fu, W., Lin, J. and Cen, P. 2007. 5-Aminolevulinate production with recombinant Escherichia coli using a rare codon optimizer host strain. - Appl. Microbiol. Biotechnol. 75: 777-782.

Ghosh, M., Pulicherla, K.K., Rekha, V.P.B., Venkat Rao, G. and Rao, K. 2012. A review on successive generations of streptokinase based thrombolytic agents. - Int. J. Pharm. Sci. 4: 38-42.

Kumar, S., Maheshwari, N. and Sahni, G. 2012. Mutants of streptokinase and their covalently modified forms. US Patent Number: 8093032 B2.

Monzavi, N., Aghasadeghi, M.R., Arabi, R., Memarnejadian, A., Sadat, S.M., Khanahmad, H., Ebrahimi, M. and Roohhvand, F. 2010. Design, cloning, expression and evaluation of cysteine-substitutes of intact and truncated molecules of streptokinase. - Iran JPP 14: 56-65.

Pimienta, E., Ayala, JC., Rodríguez, C., Ramos, A., Mellaert, L.V., Vallín, C. and Anné, J. 2007. Recombinant production of Streptococcus equisimilis streptokinase by Streptomyces lividans. - Microb. Cell Fact 6: 1-8.

Pizzo, S.V. 1991. Preparation, in vivo properties and proposed clinical use of polyoxyethylene-modified tissue plasminogen activator and streptokinase. - Adv. Drug Deliv. Rev. 6: 153-166.
بروتئين نوتركيب خالصسازى آن است. هرجه مراحل تخليص كمتر باشد، بازده توليد يروتئين بالاتر است. پيروتئينهاى استريتوكيناز توليدشده در اين مطالعه، بهواسطة داشتن برجّب برّب هيستيدينى (6xHis-tag) قابليت تخليص باستفادهاز روش كروماتو گر افى تمايلى با ستون Ni-NTA agarose را دارا بودند. باتوجه به اين كه بيان بالاى بروتئين ها در باكترى E.coli مىتواند موجب توليد يروتئين نوتر كيب بهصورت نامحلول و تشكيل اجسام تودهاى شود (Werner et al., 1994)؛ احتمال داشت كه تخليص بروتئينها در شرايط واسرشتشده، موجب كاهش بازده تخليص شود (Bornhorst \& Falke, 2000). بنابراين، خالص سازى يروتئينها در شرايط واسرشت با اوره انجام گرفت تا يروتئينها بهصورت محلول درآيند و تخليص آنها تسهيل شود. يساز تخليص با اين روش، از فيلتراسيون زلى جهت حذف اورهو تاخوردگى مجدد بروتئينها استفاده شد. از مزاياى اين روش نسبتبه روش استفاده از كيسٔ دياليز مىتوان به سادهتر بودن، كو تاهتر بودن ازلحاظ زمانى و درصد بيشتر ساختار درست بروتئين اشاره كرد. علاوهبراين، بروتئينها بِ بـاز انجام فيلتراسيون زلى احتمالاً كمى خالصتر نيز مىشوند. تنها اير اد اين روش، رقيقشدن لِّن يروتئينها يساز تعويض بافر است كه در اين مطالعه نيز مشاهده شد كه بروتئين ها حدود ها ب برابر رقيق شدهاند. اما برخلاف دياليز، در فيلتراسيون زلى احتمال جمعشدن و تاخوردگى نامناسب يروتئينها، كم است. نمودارهاى بهدست آمده از فيلتراسيون زلى لى لى يروتئين استريتوكيناز دستنخورده و جهش، گواه بر خروج اوره از نمونها بوده و محلولهاى يروتئينى حاصل، كاملاً شفاف و بدون هيج رسوب يروتئينى حاصلاز جمعشدن مشاهدشد كه اين نتايج مطابق با مطالعات ييشين (Werner et al., 1994) است. نتايج حاصلاز اين تحقيق منجربه ساخت سازه زنى و سويهاى نوتر كيب با قابليت توليد يروتئين جهشيافته با بازده مناسب شدكه

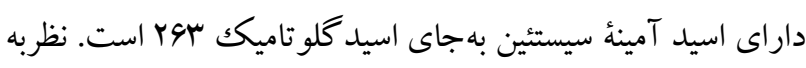
اين كه يروتئين جهشيافته ياد آورى شده حاوى اسيد آمينه سيستئين در سطح مولكول است، درصورت اثبات عدم كاهش فعاليت بيولوزيكك، انتخاب ايدهآلى براى انجام بِخيلاسيون اختصاصى در يروزههاى آتى خو اهد بود. 
Pratap, J., Rajamohan, G. and Dikshit, K.L. 2000. Characteristics of glycosylated streptokinase secreted from Pichia pastoris: enhanced resistance of SK to proteolysis by glycosylation. - Appl. Microbiol. Biotechnol. 53: 469-475.

Rachmawati, H.D.F., Darfiansyah, I.A. and Retnoningrum, D.S. 2014. PEGylation of recombinant mutein streptokinase from overproduction in Escherichia coli B121 and study on the fibrinolityc activity in vitro. - Int. J. Pharm. Pharm. Sci. 6: 137-141.

Rajagopalan, S., Pizzo, S.V. and Gonias, L.S. 1985. A nonantigenic covalent streptokinase-polyethylene glycol complex with plasminogen activator function. - J. Clin. Invest. 75: 413-419.

Reed, G.L., Houng, A.K., Liu, L., Parhami-Seren, B., Matsueda, L.H., Wang, S. and Hedstrom, L. 1999. A ca-talytic switch and the conversion of streptokinase to a fibrin-targeted plasminogen activator. - Proc. Natl. Acad. Sci. USA 96: 8879-8883.

Roberts, M.J., Bentley, M.D. and Harris, J.M. 2002. Chemistry for peptide and protein PEGylation. - Adv. Drug. Deliv. Rev. 54: 459-476.

Rother, J., Ford, G.A. and Thijs, N.S. 2013. Thrombolytics in acute ischaemic stroke: historical perspective and future opportunities. - Cerebrovasc. Dis. 35: 313-319.

Sambrook, J. and Russell, D.W. 2001. Molecular Cloning, a laboratory manual. - CSHL Press.

Sikri, N. and Bardia, A. 2007. History of streptokinase use in acute myocardial infarction. - Tex. Heart. Inst. J. 34: 318-327.

Scott, M. 1995. Cysteine-pegylated proteins. - USA Patent Number: 5766897.

Shani, G., kumar, R., Roy, C., Rajagopal, K., Nihalani, D., Sundram, V. and Yadav, M. 2007. Nucleic acid molecules encoding clot specific streptokinase fusion proteins proccessing altered plasminogen activation characteristics. - USA Patent Number: 7250503 B2.

Vellanki, R.N., Potumarthi, R., Doddapaneni, K.K., Anubrolu, N. and Mangamoori, L.N. 2013. Constitutive optimized production of streptokinase in Saccharomyces cerevisiae utilizing glyceraldehyde 3-phosphate dehydrogenase promoter of Pichia pastoris. - BioMed. Res. Int. 2013: 249-268.

Veronese, F.M. 2001. Peptide and protein PEGylation: a review of problems and solutions. - Biomat. 22: 405417.

Werner, M.H., Clore, G.M., Gronenborn, A.M., Kondoh, A. and Fisher, R.J. 1994. Refolding proteins by gel filtration chromatography. - FEBS Lett. 345: 125-130.

Wu, X.C., Ye, R., Duan, Y. and Wong, S.L. 1998. Engineering of plasmin-resistant forms of streptokinase and their production in Bacillus subtilis: streptokinase with longer functional half-life. - Appl. Microbiol. Biotechnol. 64: 824-829.

$$
* * * * *
$$

\section{How to cite this article:}

Rezaei, M., Baghbani Arani, F and Arabi Mianroodi, R. 2016. Point mutation in amino acid 263 of streptokinase gene as well as cloning and expression of the cysteine containing mutated protein. - Nova Biol. Rep. 3: 249-257

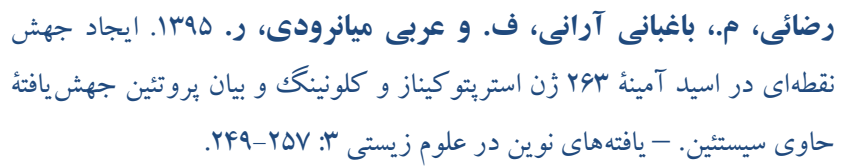

